\title{
Closed-End Country Funds and International Diversification
}

\author{
Andreas Charitou \\ University of Cyprus, Cyprus \\ Andreas Makris \\ University of Cyprus, Cyprus \\ George P. Nishiotis \\ University of Cyprus, Cyprus
}

Using data from 1993 to 2002 for eight developed and fifteen emerging markets, we find that return correlations, mean-variance spanning, and Sharpe ratio tests support that closed-end country funds (CECF) can mimic their corresponding foreign indices, and that they are more heavily influenced by their corresponding local markets instead of the U.S. market. This implies that U.S. investors, by investing in CECF, can achieve similar international diversification benefits to those achieved by investing directly in the foreign indices. We also document increased correlation between the U.S. market and foreign markets during this period and find no compelling evidence of economically and statistically significant international diversification benefits, as opposed to a pre 1993 period. These findings could be associated with the financial market liberalization that was prevalent during the period (JEL: G15).

Keywords: closed-end country funds, international diversification, emerging markets, liberalization, spanning tests.

\section{Introduction}

This paper examines the ability of closed-end country funds (CECF) to mimic their corresponding country indices and evaluates the

* We would like to thank Lenos Trigeorgis, Nikos Vafeas, Irene Karamanou and seminar participants at the University of Cyprus for useful comments. We also acknowledge financial support from the University of Cyprus and from the Institute of Certified Public Accountants of Cyprus (PriceWaterhouseCoopers, Deloitte and Touch, Ernst and Young, KPMG, Chrysanthou and Christoforou, Moore Stevens, Demetriades, Siakos, Pifanis, Gregoriou \& Co).

(Multinational Finance Journal, 2006, vol. 10, no. 3/4, pp. 251-276)

(C) Multinational Finance Society, a nonprofit corporation. All rights reserved.

DOI: $10.17578 / 10-3 / 4-4$ 
international diversification benefits available to a U.S. investor. This is done for the period 1993 - 2002 when financial markets were liberalized. For example, the net purchases of foreign stocks by U.S. investors were about $\$ 63$ billion in 1993, \$59 billion in 1996 and $\$ 95$ billion in 1999. These figures stand in marked contrast to U.S. investor purchases in the eighties, which were below $\$ 3$ billion during the entire period $1980-1989 .{ }^{1}$ While the majority of these equity flows was invested in Europe and Japan, a significant amount was invested in Latin American and Asian emerging markets. Bekaert and Harvey (2000) report that U.S. foreign ownership, as a percentage of market capitalization at the end of 1995, was around 22\% in Argentina, 19\% in Mexico and $12 \%$ in Philippines.

Various studies, such as Bailey and Lim (1992), Chang, Eun, and Kolodny (1995), Bekaert and Urias (1996) examine whether the benefits from international diversification can be achieved through the CECF. This is because a U.S. investor may find it difficult to invest directly in foreign market indices due to the high transaction costs, low liquidity and investment constraints, which are more observed in emerging markets. A closed-end country fund (CECF) is an investment company that is traded on a U.S. stock exchange but invests in the securities of a particular foreign country or a particular region. Generally, fund share prices (determined in the U.S. market) deviate from their portfolio value (determined in the local market and it is known as net asset value or NAV). As a result, the returns from holding the fund shares may differ from those of the portfolio in which the fund invests. However, CECF are actually attainable to U.S. investors and represent claims on foreign assets.

Bailey and Lim (1992) provide evidence that CECF are poor substitutes for direct holdings of foreign securities, especially emerging market funds. Chang, Eun, and Kolodny (1995) find that CECF exhibit significant exposure to the U.S. market factor and act more like U.S. securities than do their underlying assets. Furthermore, fund price and NAV are found to be cointegrated for the majority of CECF from North America and Europe, but not for those representing the Asian emerging markets. Bekaert and Urias (1996) show that the emerging market foreign indices offer superior diversification benefits compared with the U.S. emerging market funds. Errunza, Hogan, and Hung (1999) examine

1. Source: U.S. Treasury, Treasury Bulletin. The 1999 figure includes foreign stocks acquired through mergers that involved stock swaps. 
whether portfolios of domestically traded securities, not only CECF but also American Depositary Receipts (ADR), multinational corporation (MNC) stocks and U.S. industry portfolios, can mimic foreign indices. They show that for most countries this is the case. They find, however, that $\mathrm{CECF}$ alone are not enough to mimic their foreign indices.

A common characteristic of the aforementioned studies is that the time period considered ends in 1993 or earlier. A major difference with this paper is that it addresses similar questions in the most recent period starting in 1993 and ending in 2002. There is evidence in the literature implying that the ability of CECF to mimic their corresponding country indices might have improved in the nineties. For example, Bonser - Neal et al. (1990) show that the relaxation of investment restrictions in foreign financial markets causes the fund price to converge to its NAV. Patro (2002) shows that listing of new country funds also causes the fund prices of old funds to converge to their NAVS. Lee and Hong (2002) find evidence that CECF for the period 1991 - 1999 are more heavily influenced by their corresponding local market returns than by U.S. market returns. Furthermore, they show that the correlations of fund price returns with the NAV returns have increased over time. In light of this evidence, we address the question whether CECF alone can mimic their foreign indices. In other words, can a U.S. investor fully obtain international diversification benefits through the CECF alone?

The increased liberalization that is prevalent in this period also begs the question whether international diversification, especially from emerging markets, still provides a U.S. investor with significant gains. DeSantis (1994), Divecha, Drach, and Stefek (1992) and Harvey (1995a and 1995b) document that emerging markets provide U.S. investors with substantial diversification benefits, due to their low return correlations with the U.S. market. However, more recently, Kan and Zhou (2001) find no compelling evidence that a U.S. investor can benefit by diversifying in seven developed markets for the period 1970 - 1999, possibly due to the increased integration among the global equity markets.

Examining data for eight developed and fifteen emerging markets, we find that return correlations, mean-variance spanning, and Sharpe ratio tests support the hypothesis that closed-end country funds (CECF) can mimic their corresponding foreign indices, and are more heavily influenced by their corresponding local markets instead of the U.S. market. This implies that U.S. investors, by investing in CECF, can achieve similar international diversification benefits to those that can be 
achieved by investing directly in the foreign indices. We also document increased correlations between the U.S. market and foreign markets during 1993 - 2002 and find no compelling evidence of economically and statistically significant international diversification benefits, as opposed to a pre 1993 period.

The paper is organized as follows. Section II describes the sample and provides descriptive statistics. Section III examines the ability of CECF to provide similar diversification benefits to a U.S. investor as the foreign indices and if there exist substantial international diversification gains. Section IV examines the relative importance of the domestic and U.S. factor in explaining country fund price returns. Finally, in section $\mathrm{V}$ we provide some concluding remarks.

\section{Data Description}

The study examines eight CECF investing in developed markets and fifteen $\mathrm{CECF}$ investing in emerging markets. For each fund, we collected time series data for fund share prices. For some countries there exist multiple funds. In these cases we selected the fund with the longest history. ${ }^{2}$ We used Morgan Stanley Capital International market indices (MSCI) and International Finance Corporation indices (IFC) to proxy foreign markets, and their prices were obtained in US dollars. ${ }^{3}$ The New York Stock Exchange Composite Index (NYSE) was used to proxy the U.S. market portfolio, Datastream was used to obtain the observations on funds and foreign indices. As a risk-free rate, the average of the three-month T-bill rates was used and collected by the Federal Reserve Board.

Table 1, reports monthly descriptive statistics for the returns of the foreign indices for the period 1993 - 2002. Emerging market returns are characterized by high volatility ( $12.30 \%$ on average) compared to the volatility of developed markets returns ( $6.47 \%$ on average). Moreover, the average minimum and maximum returns of emerging markets are

2. Adding more than one closed-end fund for each country into our analysis would only strengthen our (already strong) results. We would essentially have a more diversified closedend fund portfolio for these countries, which would make it easier to mimic their corresponding foreign indices.

3. IFC indices were used for emerging markets in the pre 1993 period as the MSCI indices did not go back far enough. 
-33.49 and 45.16 percent, respectively, whereas the corresponding values for the developed markets are -16.44 and 21.15 percent. The average mean return of developed markets is slightly higher $(0.55 \%)$ than that of emerging markets $(0.54 \%)$. The NYSE index has a higher mean return $(0.66 \%)$ and a lower standard deviation $(3.87 \%)$ than the average mean and standard deviation of both developed and emerging markets.

Table 2, reports monthly descriptive statistics for the price returns of CECF. Emerging market CECF have higher average return volatility $(12.36 \%)$ than developed markets $(7.92 \%)$. Their average minimum and maximum returns are $-31.72 \%$ and $48.56 \%$, respectively, whereas the average minimum and maximum returns of developed market country funds are $-21.24 \%$ and $26.10 \%$, respectively.

Surprisingly, emerging market fund returns are closer to the returns of their corresponding foreign indices than developed market fund returns are to the returns of their corresponding indices. ${ }^{4}$ The difference between the mean market index and fund returns across developed markets is $0.53 \%$ and is statistically significant $(\mathrm{t}$-statistic $=6.40)$. The corresponding difference between the mean returns across emerging markets is $0.31 \%$ and is not statistically significant (t-statistic $=1.49$ ). This last finding is consistent with Nishiotis (2004), who shows that both premiums and discounts in emerging market fund prices relative to their net asset values significantly shrink towards zero after market liberalization.

\section{Country Funds as Substitutes for Direct Holdings of Foreign Equity}

\section{Comparison of correlation coefficients}

As a first step to examine the ability of CECF to provide similar diversification benefits as those of foreign indices we compare the correlation between country fund and U.S. market returns to the correlation between their corresponding foreign index and U.S. market

4. If developed countries are more integrated with the U.S. than emerging markets, we would expect country funds from developed markets to be closer to their underlying assets than the funds from emerging markets. The greater disparity for the developed country funds might be related to the closed-end fund puzzle. See Lee, Schleiffer, and Thaler (1991) for a discussion of other potential factors affecting the differential pricing of closed-end funds. 


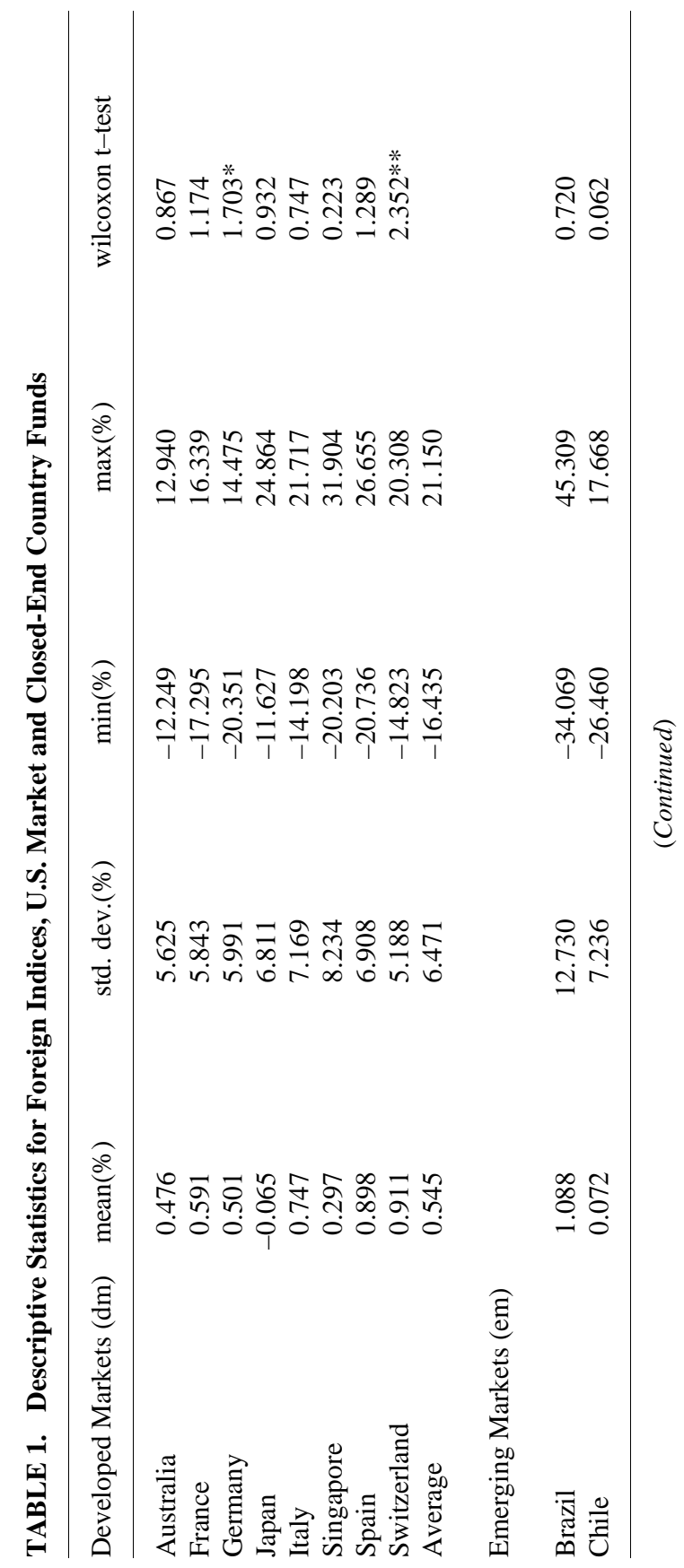




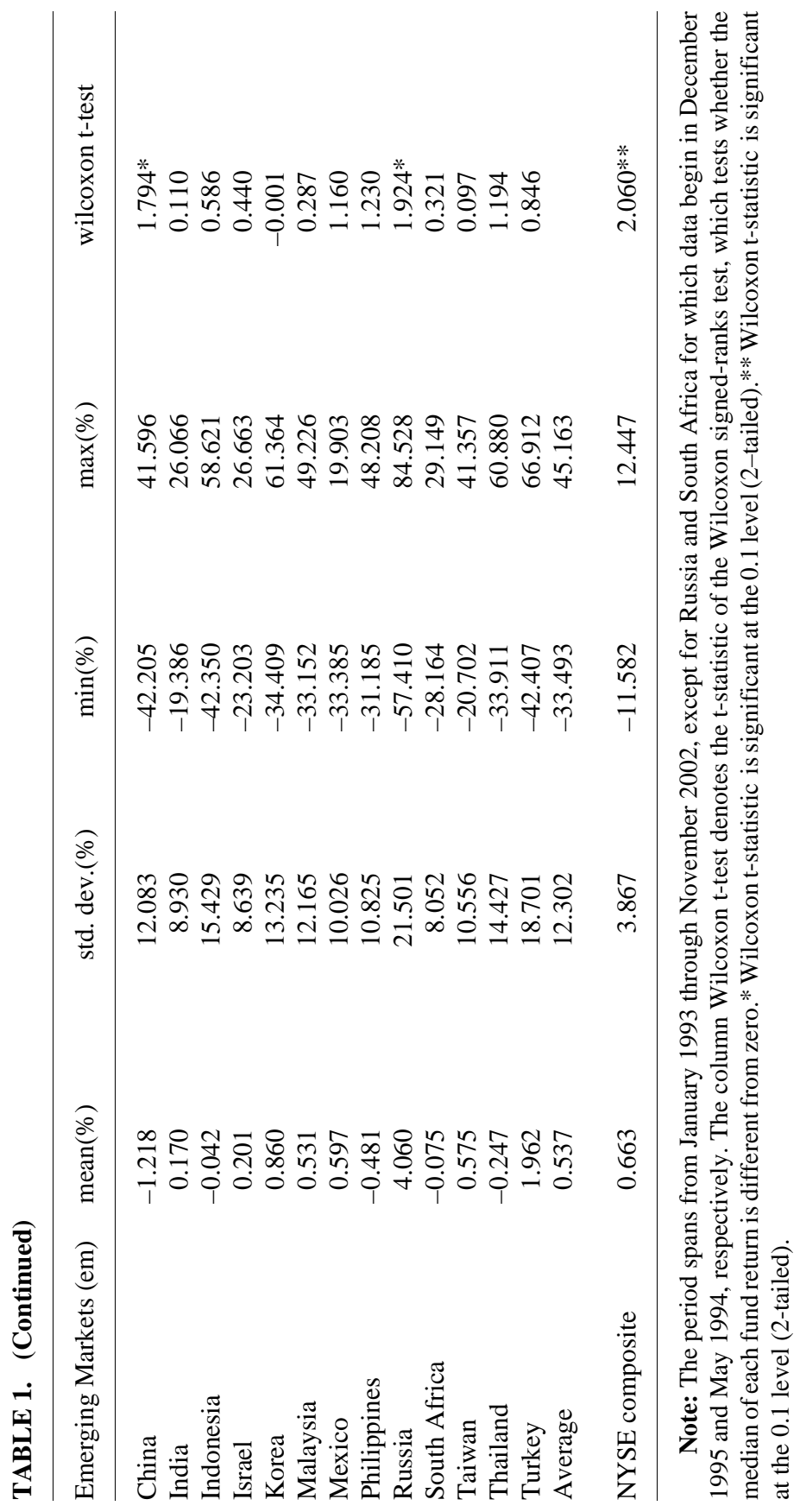




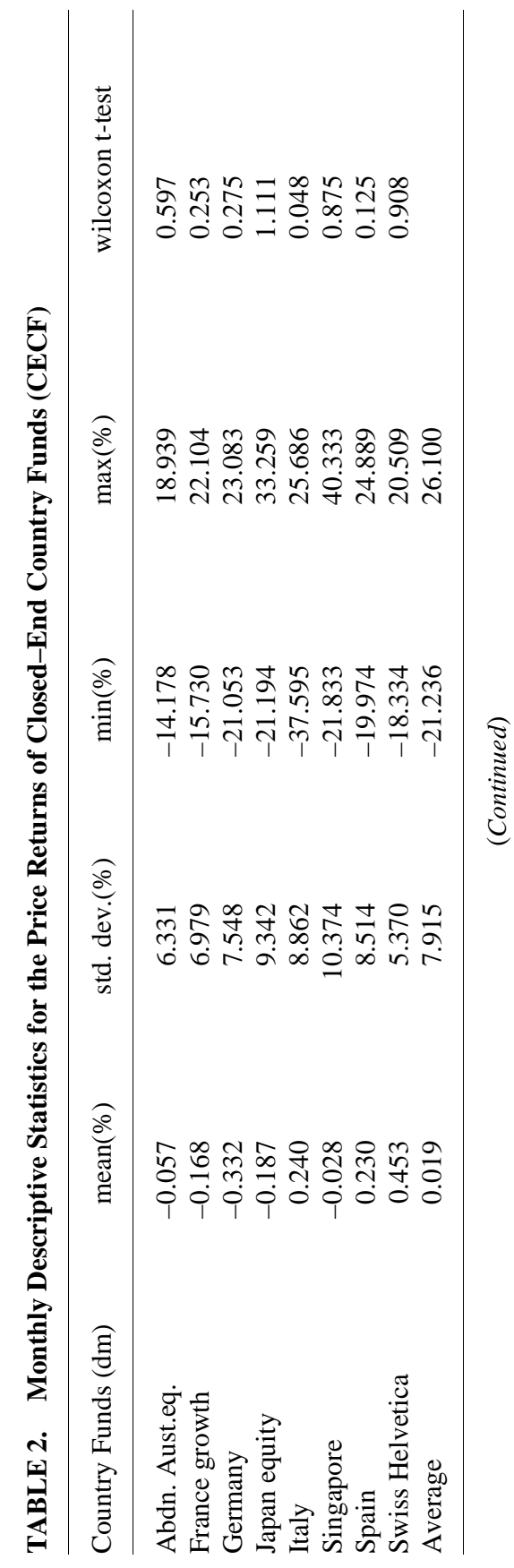




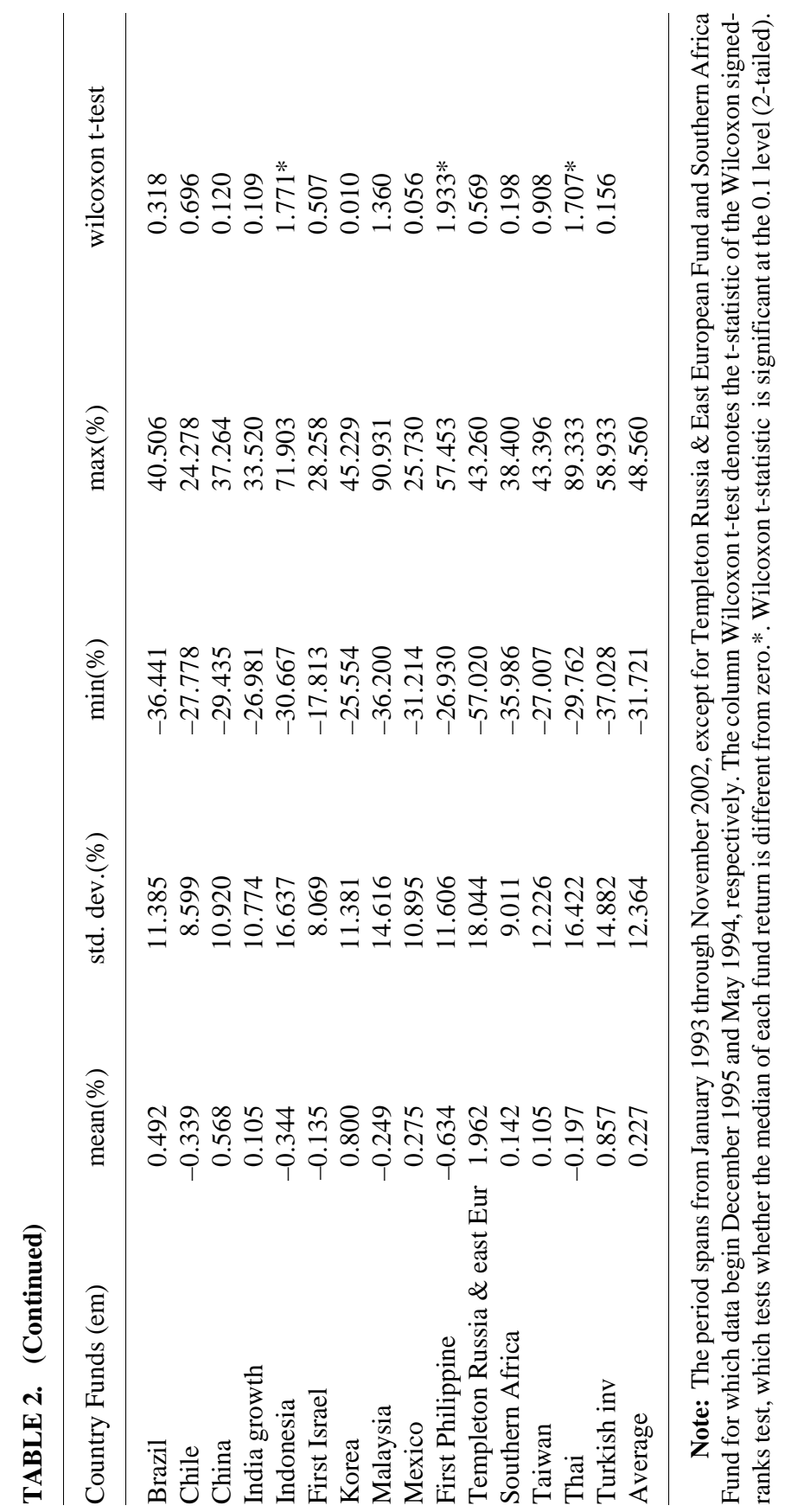


returns. Evidence that the two correlations are similar would suggest that the country fund is a good substitute for direct holdings of the underlying country's equity. This methodology was used in Bailey and Lim (1992).

Table 3, presents our results using both monthly and weekly data. The columns labeled indices and funds report the correlations of the index returns and fund returns with the U.S. market returns, respectively. Most of the correlations appear to be close to each other in both developed and emerging markets. In order to determine whether their differences are statistically significant we provide a test statistic for comparison of two correlation coefficients. The test statistic, based on Fisher $z$ transformation, is presented in the third and sixth column of table 3 for the monthly and weekly data, respectively. ${ }^{5}$ The $z$ statistic is distributed approximately as a standard normal variable under the null hypothesis, when the sample sizes are reasonably large $(>=25)$. For monthly data, we uniformly fail to reject the null hypothesis that the country fund return correlation with the U.S. market return is equal to the foreign index return correlation with the U.S. market return. The findings are similar when we use weekly data, where we fail to reject the null hypothesis for 17 out of 23 countries.

The results imply that CECF can be a good substitute for their foreign underlying assets and provide similar diversification benefits. These results stand in marked contrast to the results of Bailey and Lim (1992). They use weekly data for an earlier period and conclude that CECF do not offer the diversification benefits of their corresponding indices. ${ }^{6}$

Table 4, using monthly data, reports correlation coefficients between the U.S. market return and a number of developed and emerging market returns for two periods: the 1993 - 2002 period and an earlier period $(1983-1992) .{ }^{78}$ In all cases (except for Singapore and Malaysia) the

5. For inferences on correlation coefficients and details on the Fisher $\mathrm{z}$ transformation see Neter et al. (1996), pp. $640-645$.

6. The beginning of the data varies across funds with the data ending June 30, 1989 .

7. The qualitative findings for weekly data are very similar.

8. Note that we had to drop some emerging markets because of non-availability of index returns for the earlier period. Furthermore, the data for Malaysia, Philippines and Taiwan start on $1 / 85$ and for Turkey on $1 / 87$. 
correlations coefficients are higher in the more recent period. ${ }^{9}{ }^{10}$ The average correlation among developed markets for the pre and post 1993 period is 0.397 and 0.559 , respectively. The difference between the two is statistically significant at the $1 \%$ level (t-statistic is 4.387 ). The average correlation among emerging markets pre and post 1993 is 0.178 and 0.369 , respectively. The difference is statistically significant at the $1 \%$ level (t-statistic is 3.092). This increase in the correlation with the U.S. market for most countries signals a possible reduction in international diversification benefits.

This increase in correlations could be associated with the fact that the emerging markets in the sample underwent major financial liberalizations in the early nineties or late eighties. For example, Brazil opened in May 1991, Korea in January 1992 and India, the last market in the sample to be liberalized, in November 1992 (see Kim and Singal [2000]). Kim and Singal (2000) also report that “...stock market liberalization is often accompanied by other economic reforms, such as relaxation of product market controls, trade liberalizations and privatization." For example, a careful examination of the Emerging Stock Markets Factbook reveals that the market openings of Brazil, India and Mexico were part of a more general plan of fiscal reforms and privatization. While the market liberalizations improved the ability of foreign investors to invest in emerging markets, the economic and other reforms increased their willingness to do so. ${ }^{11}$ The figures on net purchases of foreign stocks by U.S. investors reported in the introduction confirm these liberalizations. Net purchases were below $\$ 3$ billion for the entire 1980 - 1989 period and \$63 billion just in 1993 . The 1993 - 2002 period we examine in this paper is a period when all markets are open and most countries had already undergone economic and other reforms that made them more attractive and accessible to foreign investors.

9. For Malaysia the correlation with the U.S. in the post 1993 period drops to less than half of what it was during the pre 1993 period. This drop is consistent with the reintroduction of strong capital controls in September 1998 after the market has been opened since 1984 or earlier (see Kim and Singal [2000]).

10. This result is consistent with Solnik, Bourcelle, and Le Fur (1996) who show that there is a tendency for return correlations to increase over time and Bekaert and Harvey (2000) who argue that correlations and betas with the world market increase after equity market liberalizations.

11. For further discussion of the effects of investment barriers on market integration see Bekaert (1995) and Nishiotis (2004). 


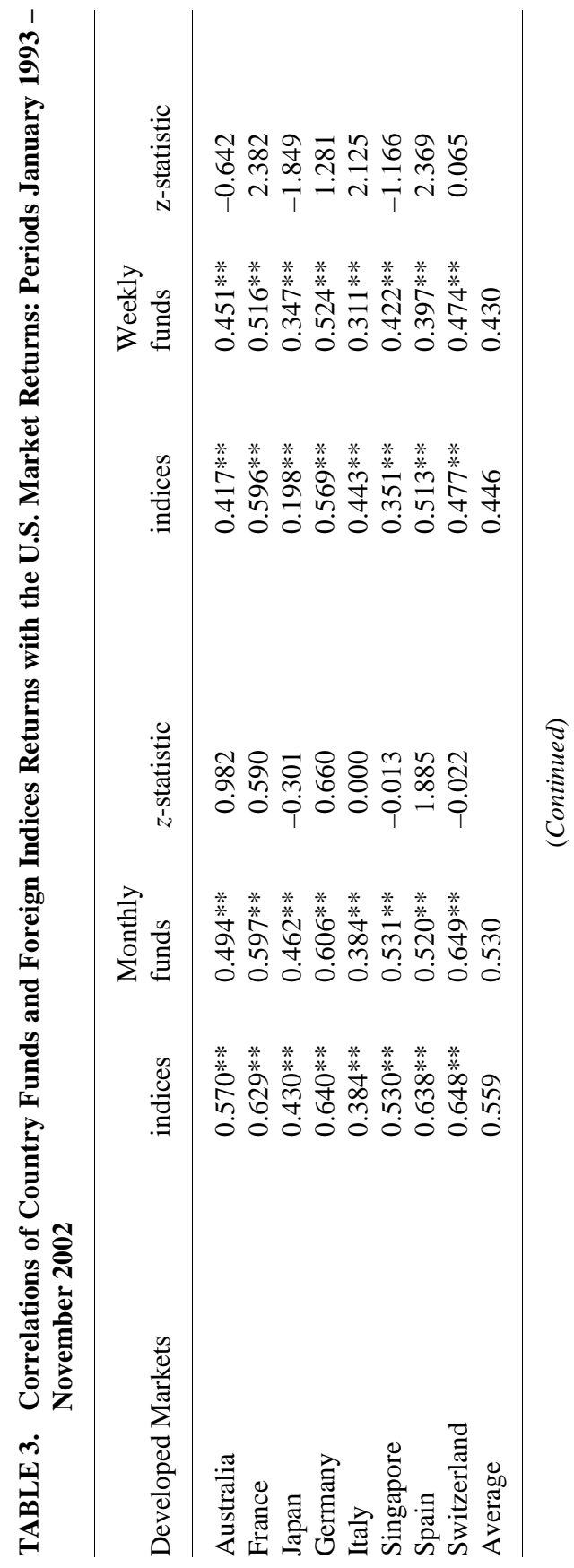




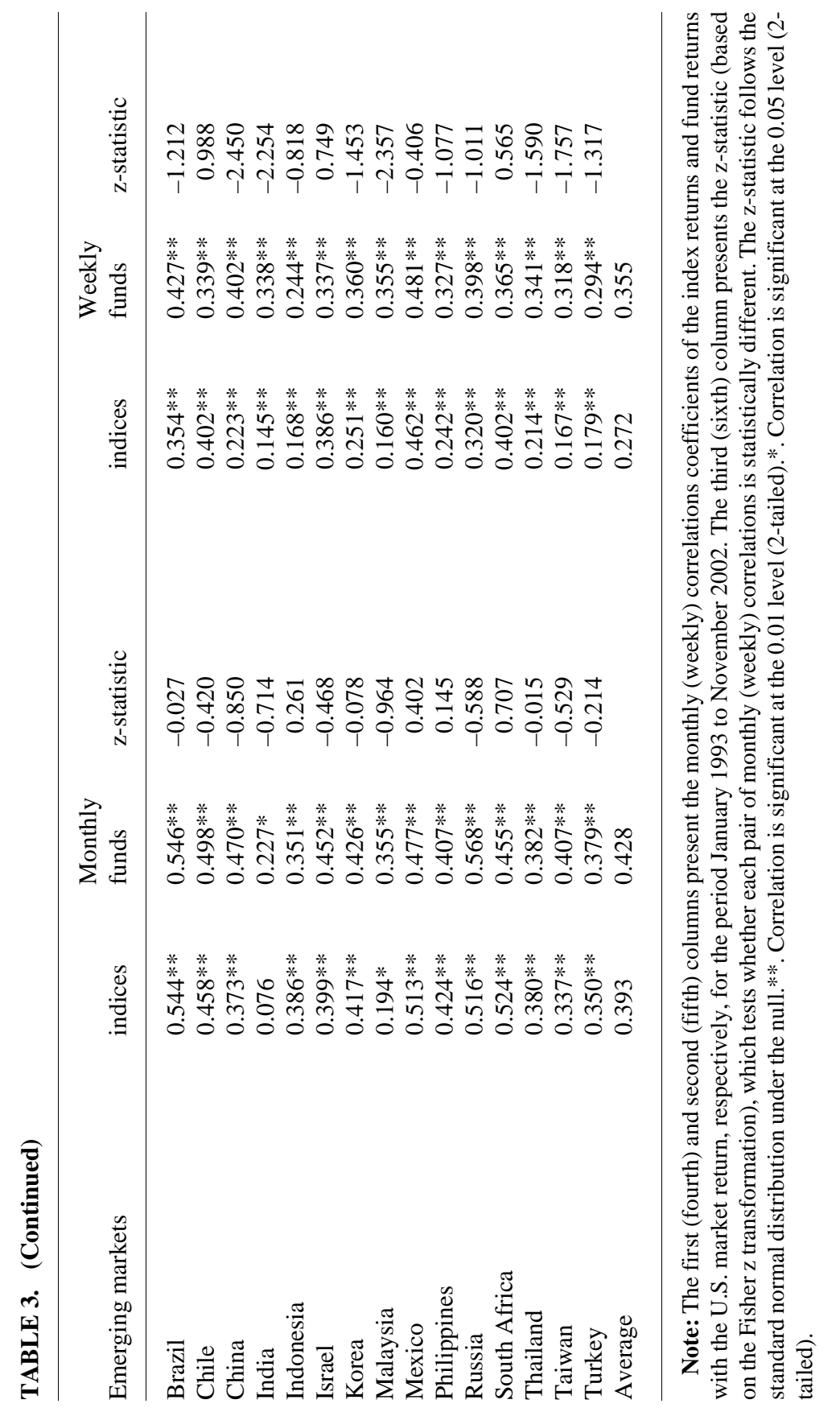


TABLE 4. The Monthly Correlations of the U.S. Market With the Developed Market Returns

\begin{tabular}{lcc}
\hline Developed Markets (dm) & $1983-1992$ & $1993-2002$ \\
\hline Australia & $0.426^{* *}$ & $0.570^{* *}$ \\
France & $0.468^{* *}$ & $0.629^{* *}$ \\
Japan & $0.227^{* *}$ & $0.430^{* *}$ \\
Germany & $0.348^{* *}$ & $0.640^{* *}$ \\
Italy & $0.285^{* *}$ & $0.384 * *$ \\
Singapore & $0.567^{* *}$ & $0.530^{* *}$ \\
Spain & $0.360^{* *}$ & $0.638^{* *}$ \\
Switzerland & $0.495^{* *}$ & $0.648^{* *}$ \\
Average & 0.397 & 0.559 \\
Emerging Markets (em) & & \\
\hline Brazil & $1983-1992$ & $1993-2002$ \\
Chile & 0.073 & $0.544 * *$ \\
India & 0.137 & $0.458 * *$ \\
Korea & -0.099 & 0.076 \\
Malaysia & 0.093 & $0.417 * *$ \\
Mexico & $0.462^{* *}$ & $0.194 *$ \\
Philippines & $0.332^{* *}$ & $0.513^{* *}$ \\
Thailand & $0.218^{*}$ & $0.424 * *$ \\
Taiwan & $0.315^{* *}$ & $0.380^{* *}$ \\
Turkey & 0.157 & $0.337 * *$ \\
Average & 0.091 & $0.350^{* *}$ \\
\hline
\end{tabular}

Note: The monthly correlation coefficients of the U.S. market with the developed market returns and the emerging-market returns are presented for the 1983-1992 period and for the 1993 - 2002 period. We had to drop some emerging markets because of non-availability of index returns for the earlier period. Furthermore, the data for Malaysia, Philippines and Taiwan start on $1 / 85$ and for Turkey on 1/87. ** Correlation is significant at the 0.01 level (2-tailed). * Correlation is significant at the 0.05 level (2-tailed).

In summary, this subsection provides two important implications for international diversification. First, it appears that international diversification benefits that can be achieved by investing in country indices can also be achieved by investing in the corresponding CECF. Second, the correlations among international capital markets and the U.S. capital market have increased in recent years implying that the gains from international diversification may have been reduced. In the next two subsections we investigate these claims more formally, by conducting mean-variance spanning tests and estimating efficient frontiers. 
Mean-variance spanning tests

In this section we examine whether CECF can mean-variance span their corresponding market indices and thus allow U.S. investors to mimic these indices using only the domestically traded country funds and the U.S. index. Huberman and Kandel (1987) show that for any partition of assets into a set of test assets and benchmark assets, the inclusion of additional test assets into the set of benchmark assets shifts the efficient frontier to the left if, and only if, the test assets are not mean-variance spanned by the benchmark assets.

Errunza, Hogan, and Hung (1999) conduct similar tests for the period 1976 - 1993, but use as benchmark assets in addition to CECF three other domestically traded portfolios. They find that CECF, ADR and MNC stocks in addition to U.S. industry portfolios mean-variance span the foreign indices for most countries and thus allow U.S. investors to achieve home-made diversification benefits. Given our findings for the period 1993 - 2002 that CECF and their corresponding foreign indices have similar return correlations with the U.S. market, we examine whether in this more recent period, U.S. investors could achieve home-made diversification benefits merely by using the CECF.

As in Errunza, Hogan, and Hung (1999), we use the Huberman Kandel (HK) F-test. However, Kan and Zhou (2001) identify a typo in the Huberman and Kandel (1987) original paper, which unfortunately carried over to a number of studies that followed. ${ }^{12}$ Furthermore, they show that the HK F-test was incorrectly used by some studies for the single test asset case. In the present study, as in Errunza, Hogan, and Hung (1999), the number of test assets is equal to one. We use the correct HK F-statistic as stated in Kan and Zhou (2001, equation 27). The HK F-test involves estimation of the following equation:

$$
R_{i, t}=a_{i}+\beta_{1} R_{U S, t}+\beta_{2} R_{C E C F, t}+\varepsilon_{I, t}
$$

where $R_{I, t}$ is the return on the $I$-th foreign index, $R_{U S, t}$ is the return of the U.S. market and $R_{C E C F, t}$ is the price return of the $I$-th country fund. Huberman and Kandel (1987) show that $R_{I, t}$ is spanned by $R_{U S, t}$ and $R_{C E C F, t}$ if and only if the following two conditions hold:

12. For more details and reference of the studies affected by this error see Kan and Zhou (2001) 
TABLE 5. Tests of Mean-Variance Spanning

\begin{tabular}{|c|c|c|}
\hline Developed Markets & HK F-test & $\mathrm{p}$-value \\
\hline Australia & 0.706 & 0.496 \\
\hline France & 1.712 & 0.185 \\
\hline Germany & 1.344 & 0.265 \\
\hline Japan & 4.270 & 0.016 \\
\hline Italy & 2.120 & 0.125 \\
\hline Singapore & 0.194 & 0.824 \\
\hline Spain & 1.205 & 0.303 \\
\hline Switzerland & 1.496 & 0.228 \\
\hline Emerging Markets & HK F-test & p-value \\
\hline Brazil & 1.771 & 0.175 \\
\hline Chile & 2.999 & 0.054 \\
\hline China & 2.800 & 0.065 \\
\hline India & 7.610 & 0.001 \\
\hline Indonesia & 0.450 & 0.639 \\
\hline Israel & 0.118 & 0.889 \\
\hline Korea & 0.565 & 0.570 \\
\hline Malaysia & 2.157 & 0.120 \\
\hline Mexico & 0.392 & 0.676 \\
\hline Philippines & 0.028 & 0.972 \\
\hline Russia & 1.665 & 0.196 \\
\hline South Africa & 0.525 & 0.593 \\
\hline Thailand & 0.090 & 0.914 \\
\hline Taiwan & 1.741 & 0.180 \\
\hline Turkey & 1.011 & 0.367 \\
\hline eqw. portfolio & 3.457 & 0.035 \\
\hline
\end{tabular}

Note: The HK F-test tests the null hypothesis of spanning. Each foreign index is used as a test asset each time. Each benchmark set includes the NYSE index and the associated closed-end country fund. The last row of the table performs a test having as test asset an equally weighted portfolio of foreign indices and as benchmark assets the NYSE index and an equally weighted portfolio of country funds. Russia and South Africa and their corresponding funds are excluded from this test because their data do not begin at the same dates as those of the other countries in our sample.

$$
\begin{gathered}
a_{i}=0 \\
\sum_{i=1}^{2} \beta_{i}=1
\end{gathered}
$$

They test these restrictions based on OLS estimates of equation (1). 
Table 5 reports the correct HK F-tests for the null hypothesis of spanning and the corresponding $\mathrm{p}$-values.

We do not reject spanning for 21 countries (except Japan and India) at the 95 percent level of significance, which implies that CECF can mimic their corresponding foreign markets. For Japan, we do not reject spanning at the 99 percent level of significance. However, the India Growth Fund seems to be a poor substitute for the Indian market. At the end of the table we report the results of a test where the test asset is an equally weighted portfolio of foreign indices and the benchmark assets are the U.S. market portfolio and an equally weighted portfolio of CECF. ${ }^{13}$ In this case we do not reject spanning at the 97.5 percent level of significance.

\section{Efficient frontiers and Sharpe ratios}

In this section we assess the diversification benefits of a U.S. investor that chooses to invest in a portfolio of CECF in addition to the U.S. market and compare these benefits to those achieved by investing in a portfolio of foreign indices and the U.S. market. We achieve this by plotting the efficient frontiers from the two sets of assets and comparing the Sharpe ratios of the corresponding tangency portfolios.

Figure 1 presents the efficient frontier of indices with the U.S. market and the efficient frontier of funds with the U.S. market. ${ }^{14}$ The NYSE Composite Index is also presented alone. The efficient frontier using the indices is above the frontier with the CECF and the difference is higher for high variance portfolios. However, the graphical analysis does not answer the question of whether the frontier significantly shifts to the left. Bekaert and Urias (1996) suggest that economic significance can be assessed by evaluating the change in the Sharpe ratio. To test whether the change in the Sharpe ratio is statistically significant is difficult due to its unknown distribution. Bekaert and Urias (1996), using Monte Carlo techniques, find that changes in the Sharpe ratio of less than 0.057 are not statistically significant at a 95 percent level of

13. Russia and South Africa are excluded because of non-availability of data for the entire period

14. The frontiers are estimated using monthly data from the $1993-2002$ period. Russia and South Africa are excluded for the same reason as above. The efficient frontiers are constructed using historical returns and under a short sales constraint. 


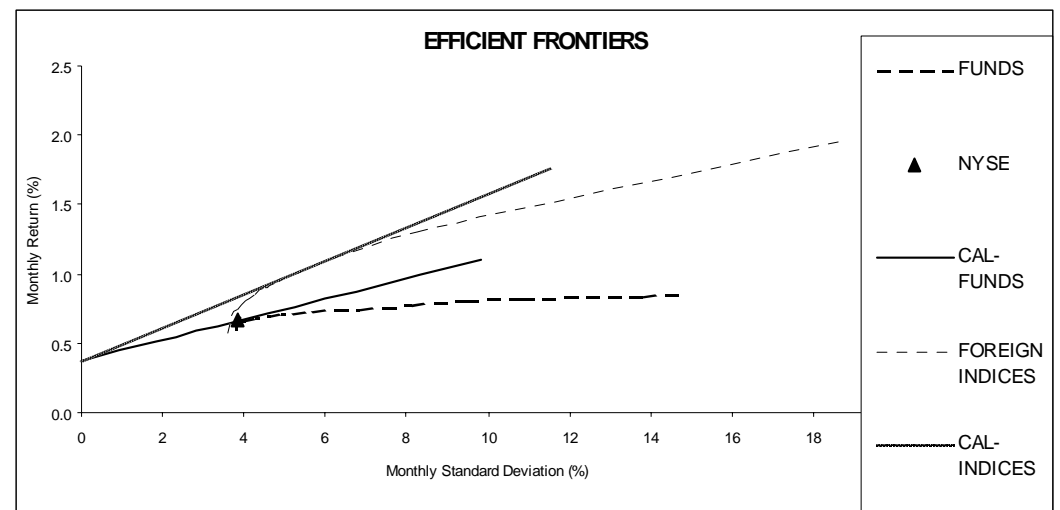

FIGURE 1.-Foreign Markets vs. Closed-End Country Funds.

The efficient frontier of foreign indices with the U.S. market, the efficient frontier of country funds and the U.S. market and the U.S. market alone are presented for the period 1993 to November 2002. Frontiers are constructed using historical monthly returns under a short sale constraint. The Capital allocation line (CAL) for each of the frontiers is also presented using the average of the three-month T-bill rate, as a risk-free rate.

significance. ${ }^{15}$ Considering the change in the Sharpe ratio between the two frontiers, we observe that the tangency portfolio of the frontier with the foreign indices and the NYSE index has a Sharpe ratio that is 0.047 higher than that of CECF and the NYSE index. If we were to follow the Bekaert and Urias (1996) critical value of 0.057, it would appear that the difference is not statistically different from zero and CECF provide similar diversification benefits with the foreign markets. This finding is consistent with the spanning test results.

Another noteworthy result is that we find no compelling evidence that a U.S. investor can significantly benefit from international diversification. The NYSE index has a Sharpe ratio equal to the one of the tangency portfolio of the frontier with the CECF and only 0.047 lower than the Sharpe ratio of the tangency portfolio of the frontier with the foreign indices. This result is consistent with the findings of Kan and Zhou (2001), who find no compelling evidence that a U.S. investor can benefit from international diversification using seven developed country indices. However, the findings here are stronger as the sample

15. The Bekaert and Urias (1996) study is based on 152 observations. Our results are based on 118 observations. Thus, applying their simulation results to our sample is an approximation at best. Errunza, Hogan and Hung (1999) also use the Bekaert and Urias (1996) critical values. 
also includes a significant number of emerging markets. ${ }^{16}$

In order to evaluate our earlier findings that correlations of international market returns with the U.S. have increased in the period 1993 - 2002 compared to the period 1983 - 1992, we compute the efficient frontier using the NYSE and country indices for the earlier period. Figure 2 plots the frontier and the NYSE portfolio. The difference in the Sharpe ratio of the tangency portfolio with that of the NYSE is 0.237, which according to the critical value of Bekaert and Urias (1996) is highly significant. This difference in the Sharpe ratio indicates statistically and economically significant diversification benefits for the U.S. investors as opposed to the findings in figure 1, where we used data for the more recent period..$^{17}$ This is consistent with our earlier finding of increased return correlations in the more recent period relative to the earlier period. Bekaert, Harvey, and Ng (2002) also document an increase in correlation around financial liberalizations, but they argue that it is not enough to reduce the diversification benefits offered, unlike what we find for the post liberalization period $1993-2002$.

\section{The Relative Importance of the Domestic and U.S. Factors in Explaining Country Fund Returns}

As a final test of the ability of CECF to mimic the underlying equity markets, we examine the relative importance of the domestic and U.S. factor in explaining country fund price returns. We follow the methodology of Errunza, Senbet and Hogan (1998). Firstly, we compute the $R_{2}$ from the regression of the country fund price return $\left(R_{c}\right)$ on each of the factors in isolation; i.e., the return on the foreign market $\left(R_{I}\right)$ and the U.S. market $\left(R_{u s}\right)$. Next, we compute first order partial correlation coefficients, i.e.,

16. Gorman and Jorgensen (2002) argue against the theoretically attainable international diversification benefits and show that extreme home bias asset allocations are insignificantly different from optimal allocations.

17. Note that the frontier in figure 2 does not include China, Indonesia, Israel, Malaysia, Philippines, Taiwan and Turkey, which are included in figure 1. For these countries, we do not have data for the entire 1983 - 1992 period. 


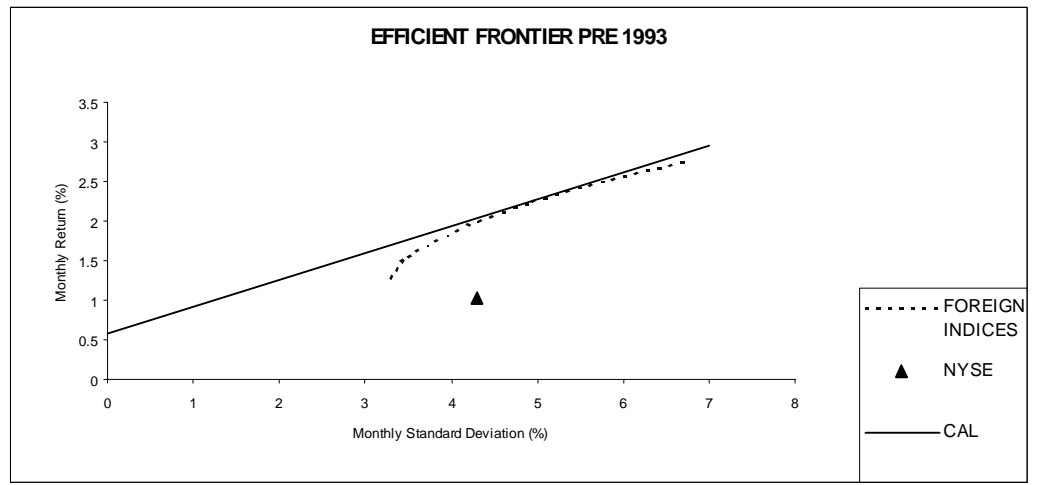

FIGURE 2.- Foreign Markets vs. U.S. Market

The efficient frontier of foreign indices with the U.S. market and the U.S. market alone are presented for the period 1983 to 1992. This frontier does not include China, Indonesia, Israel, Malaysia, Philippines, Taiwan and Turkey, which are included in figure 1. For these countries, we do not have data for the entire 1983 - 1992 period. Frontiers are constructed using historical monthly returns under a short sale constraint. The Capital allocation line (CAL) of the frontier is also presented using the average of the three-month T-bill rate, as a risk-free rate.

$$
\rho\left(R_{c} R i / R j\right)=\frac{\rho\left(R_{c}, R_{i}\right)-\rho\left(R_{c}, R_{i}\right) \rho\left(R_{c}, R_{j}\right)}{\sqrt{1-\rho\left(R_{c}, R_{i}\right)^{2}} \sqrt{1-\rho\left(R_{c}, R_{j}\right)^{2}}} \text { for } i \neq j
$$

The square of the partial correlation represents the portion of the country fund price return explained by factor $i$ after controlling for factor $j$.

Table 6 presents the results. $A$ is for the period $1993-2002$ and $B$ is for the pre 1993 period. ${ }^{18}$ The first column in both panels presents the squared correlation coefficient between funds and their corresponding index returns and the third column presents the squared correlation coefficient between fund and U.S. market returns. These correlations explain the portion of the variance of the fund price return explained by the domestic market alone and by the U.S. market alone, respectively. For the 1993-2002 period we observe that the domestic factor explains a large portion of the variance of the funds (on average 0.618 for the emerging markets and 0.622 for the developed markets) and much larger than the U.S. factor (on average 0.189 for the emerging markets and

18. For the pre 1993 period data start with the starting date of each fund except for Mexico, which starts on 1/1/1983 and Italy, which starts on 1/1/1987. 
0.288 for the developed markets). For the pre 1993 period, the domestic factor is also more important than the U.S. factor but their difference is much smaller than the corresponding difference in the $1993-2002$ period (on average 0.166 as opposed to 0.334 for developed markets and 0.168 as opposed to 0.429 for emerging markets).

The second (fourth) column in both panels presents the squared first order partial correlation coefficient of the country fund return with the domestic (U.S.) factor net of the effects of the U.S. (domestic) factor. For the $1993-2002$ period, the correlations between the funds and foreign indices net of the effects of the U.S. factor remain in high levels, showing a small decline (on average 0.551 for the emerging markets and 0.489 for the developed markets). The correlations between the funds and U.S. market net of the effects of the domestic factor show a greater decline with very low absolute levels. They are on average, 0.043 for the emerging markets and 0.036 for the developed markets. The corresponding figures for the pre 1993 period are 0.136 and 0.062 , respectively.

The findings for the 1993-2002 period reveal that fund returns are more heavily influenced by their corresponding markets and much less by the U.S. market and are consistent with the evidence provided by Lee and Hong (2002), who examine in a VAR framework the dual characteristics of CECF for the period $1991-1999$. We also find that the importance of the domestic factor net of the effect of the U.S. factor has increased and the importance of the U.S. factor net of the effect of the domestic factor has decreased for both developed and emerging markets in the 1993 - 2002 period relative to the pre 1993 period. Our results are significantly different from the findings of Chiang, Eun and Kolodny (1995) and Bodurtha, Kim and Lee (1995), who provide evidence that country funds exhibit significant exposure to the U.S. market. Bodurtha, Kim and Lee (1995) suggest that the significant U.S. factor in closed-end fund prices may be interpreted as U.S. market sentiment affecting the discounts in closed-end fund prices. Our results however, are consistent with a rational, market segmentation explanation of discounts/premiums, which is proposed by Swaminathan (1996) for U.S. domestic funds and by Nishiotis (2004) for emerging market funds. As markets become more integrated with the U.S., fund share prices align with the prices of their underlying assets. 


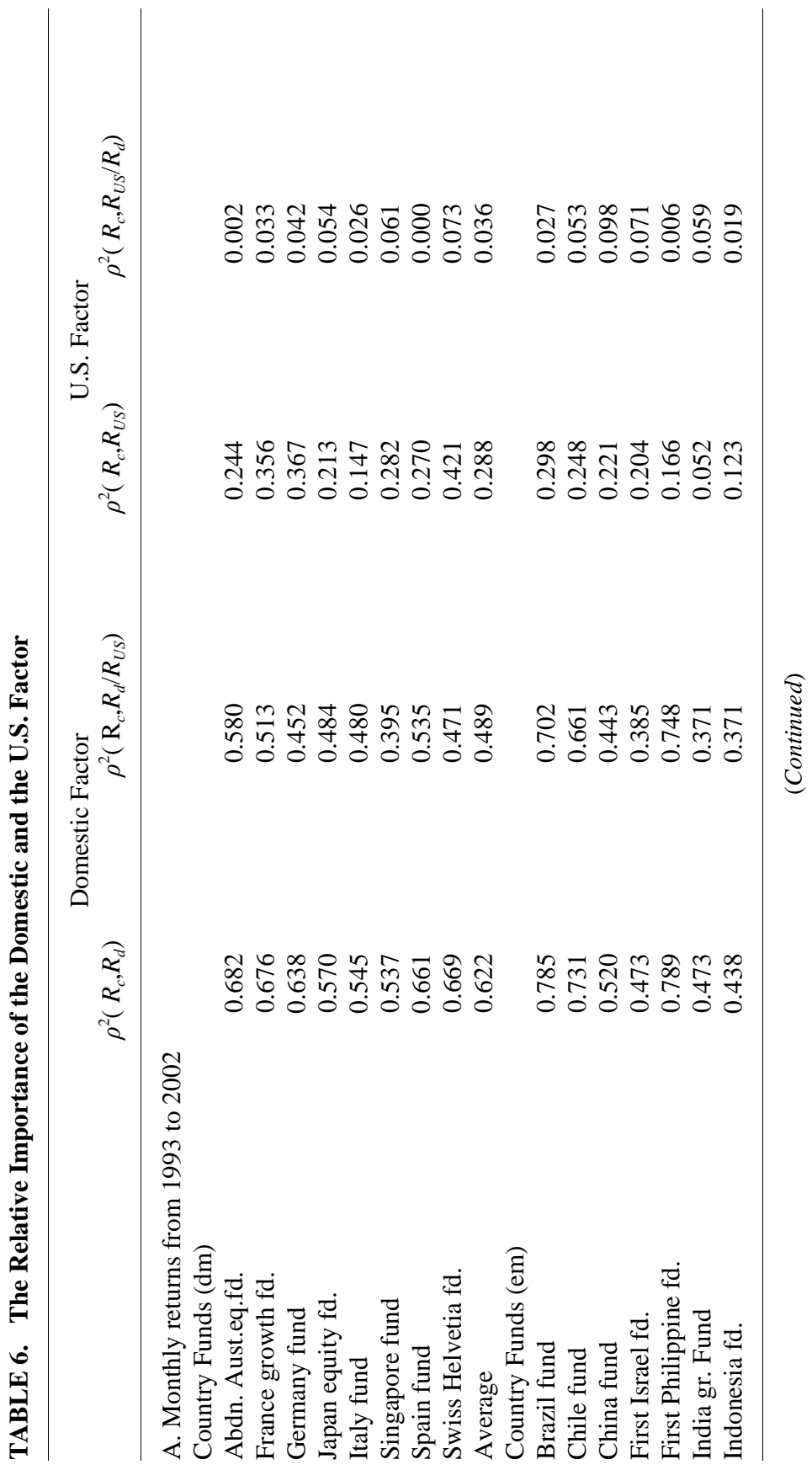




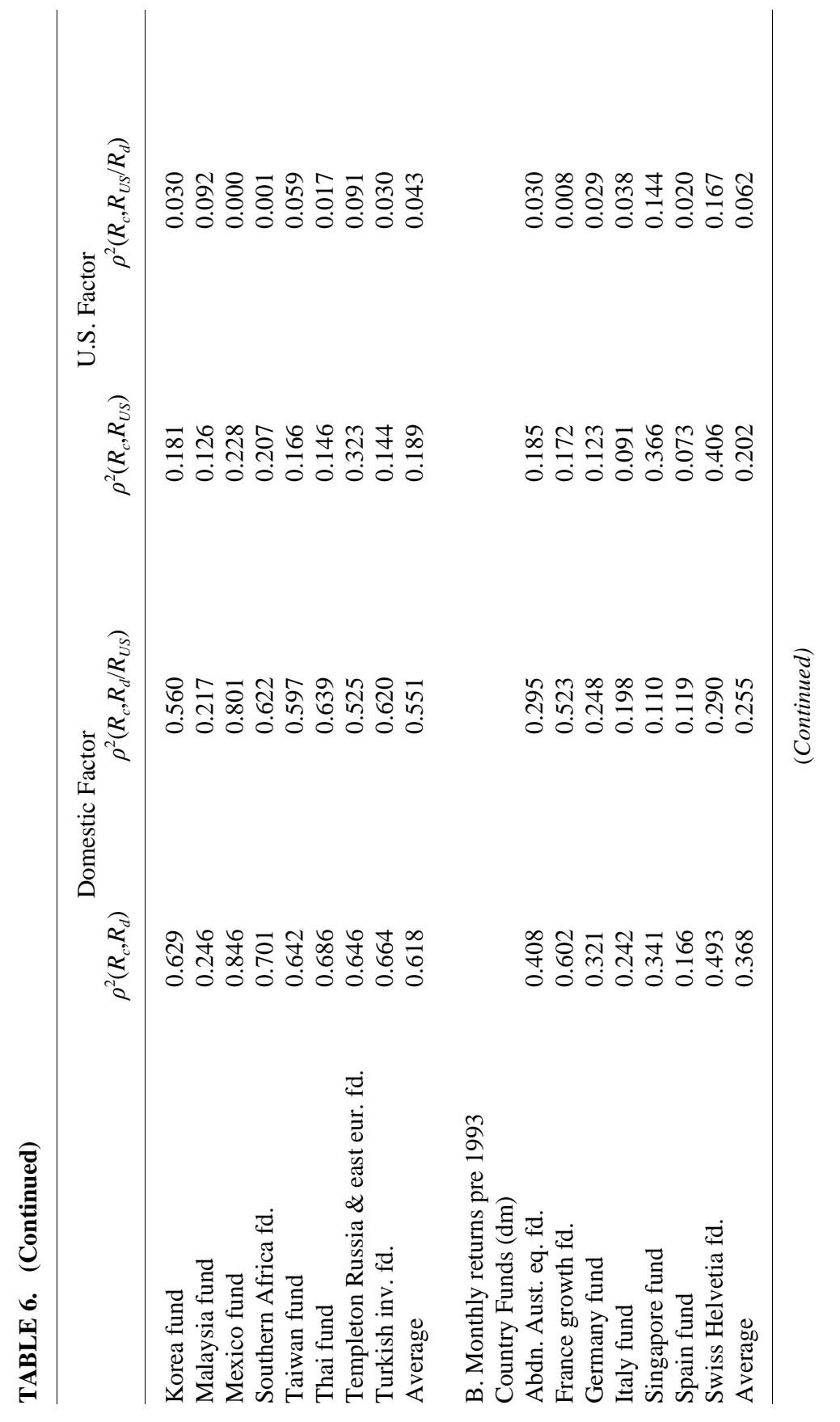




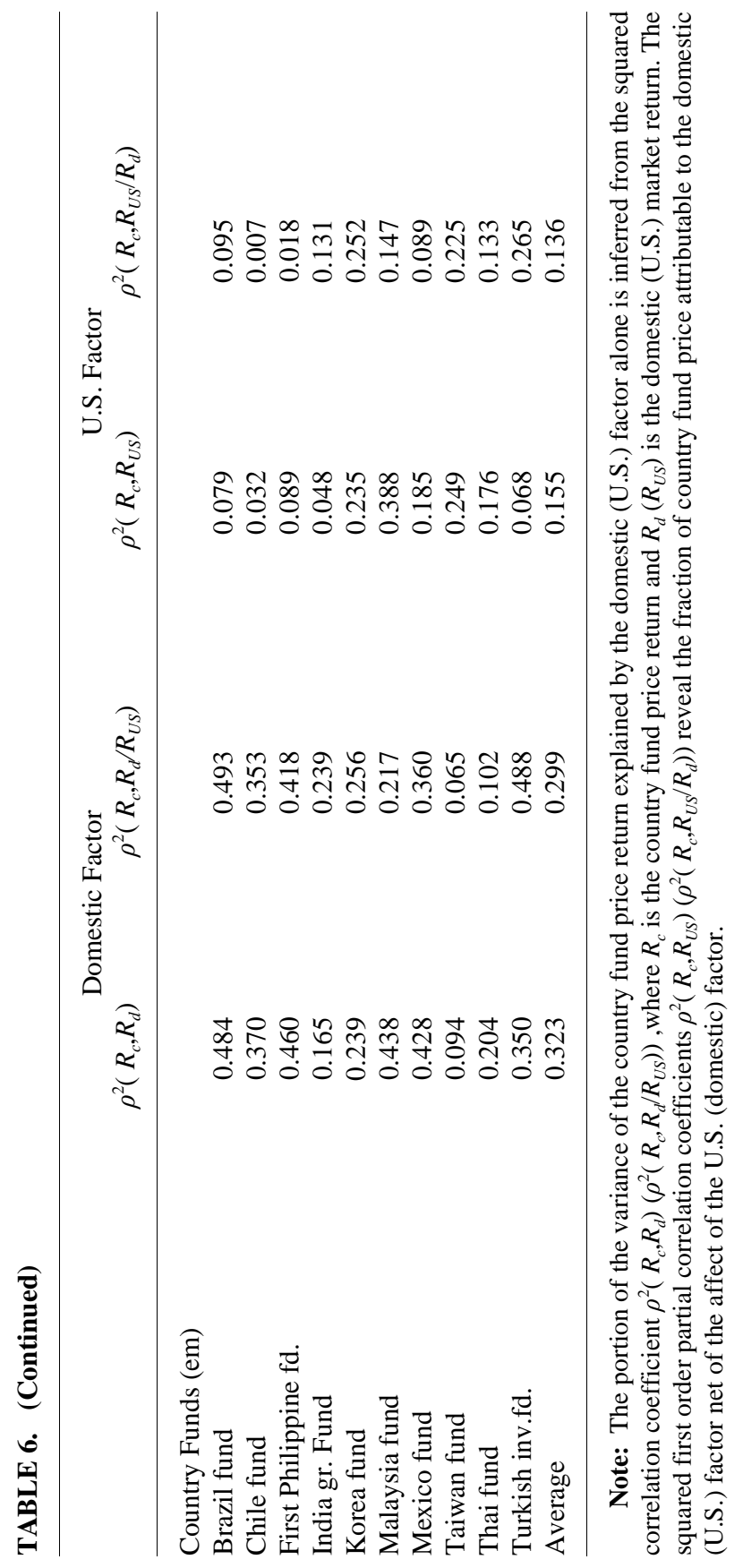




\section{Conclusion}

In light of the liberalization of world financial markets in the nineties, this paper addresses two important questions. First, can CECF trading in the U.S. mimic their corresponding country indices? Second, are there still significant international diversification benefits from the point of view of a U.S. investor? The results for the period $1993-2002$ differ significantly from those of prior studies that investigate earlier, preliberalization, periods, and from our own pre 1993 analysis. We find strong evidence that CECF can mimic their foreign indices and are more heavily influenced by the local factor than by the U.S. factor. We also document increased correlation between the U.S. market and foreign markets during the 1993-2002 period and find no compelling evidence of economically and statistically significant diversification benefits, as opposed to the pre-1993 period.

\section{References}

Bailey; Warren, and Lim, Joseph, 1992. Evaluating the diversification benefits of the new country funds Journal of Portfolio Management. 18: 74-80.

Bekaert, Geert, 1995. Market integration and investment barriers in emerging equity markets. The World Bank Economic Review. 9: 75-107.

Bekaert, Geert; Harvey, R. Campbell; and Ng, Angela, 2002. Market integration and contagion. Working paper. Columbia University, Duke University, National Bureau of Economic Research, and Hong Kong University of Science and Technology.

Bekaert, Geert, and Harvey, R. Campbell, 2000. Foreign speculators and emerging equity markets. Journal of Finance. 55: 565-613.

Bekaert, Geert, and Urias, Michael S. 1996. Diversification, integration and emerging market closed-end funds. Journal of Finance. 51: 835-869.

Bodurtha Jr., James N.; Dong-Soon, Kim; and Lee, Charles M.C., 1995. Closed-end country funds and U.S. market sentiment. The Review of Financial Studies. 8: 879-918.

Bonser -Neal, Catherine; Brauer, Gregory; Neal, Robert; and Wheatly, Simon 1990. International investments restrictions and closed-end country fund prices. Journal of Finance. 45, 523-547.

Chang, E; Eun, C.S.; and Kolodny, R., 1995. International diversification through closed-end country funds. Journal of Banking and Finance. 19: 1237-1263.

DeSantis, Giorgio, 1994. Asset pricing and portfolio diversification: Evidence from emerging financial markets. in Mike Howell, ed.: Investing in 
Emerging Markets (Euromoney Books, London).

Divecha, A.B.; Drach, J.; and Stefek, D., 1992. Emerging markets: A quantitative perspective. Journal of Portfolio Management., 19: 41-50.

Erb, C.; Harvey, C.; and Viskantas, T., 1994. Forecasting international correlation. Financial Analysts Journal. 50 (6): 32-45.

Errunza, Vihang; Hogan, Ken; and Wei Hung, Mao, 1999. Can the gains from international diversification be achieved without trading abroad? Journal of Finance 6: 2075-2107.

Errunza, Vihang; Senbet, Lemma; and Hogan, Ked, 1998. The pricing of country funds from emerging markets: Theory and evidence. International Journal of Theoretical and Applied Finance. 1: 111-143.

Gorman, Larry R., and Jorgensen, Bjorn N., 2002. Domestic versus international portfolio selection: A statistical examination of the home bias. Multinational Finance Journal 6: 131-166.

Harvey, R. Campbell, 1995a. Predictable risk and returns in emerging markets. Review of Financial Studies 8: 773-816.

Harvey, R. Campbell, 1995b. The risk exposure of emerging equity markets. World Bank Economic Review 9:19-50.

Huberman, Gur, and Kandel, Shmuel, 1987. Mean -variance spanning. Journal of Finance 42: 873-888.

Kan, Raymond, and Zhou, Guofu, 2001. Tests of mean-variance spanning. Working paper, University of Toronto and Washington University in St. Louis.

Kim, E. Han, and Singal, Vijay, 2000. Stock markets openings: Experience of emerging economies. Journal of Business 73: 25-66.

Lee, Bong-Soo, and Hong, Gwangheon, 2002. On the dual characteristics of closed -end country funds. Journal of International Money and Finance 21:589-618.

Lee, C. M. C.; Shleifer, A.; and Thaler, R., 1991. Investor sentiment and the closed -end fund puzzle. Journal of Finance 46: 75-109.

Neter, John; Kutner, M.H.; Nachtsheim, C.J.; and Wasserman, W., 1996. Applied Linear Statistical Models McGraw-Hill, fourth edition.

Nishiotis, P. George, 2004. Do indirect investment barriers contribute to capital market segmentation?. Journal of Financial and Quantitative Analysis 39: 613-630.

Patro, K. Dilip, 2002. Stock market liberalization and emerging market country fund premiums. Working paper, Rutgers University.

Schwebach, G., Robert; Olienyk, P. Jhon; and Zumwalt, K. Jenton, 2002. The impact of financial crises on international diversification. Global Finance Journal 13:147-161.

Solnik, B.; Bourcelle, C.; and Le Fur, Y., 1996. International market correlation and volatility. Financial Analysts Journal 52: 17-34.

Swaminathan, B., 1996. Time varying expected small firm returns and closedend fund discounts. Review of Financial Studies 9: 845-887. 